Article

\title{
Navigating the Wildfire-Pandemic Interface: Public Perceptions of COVID-19 and the 2020 Wildfire Season in Arizona
}

\author{
Catrin M. Edgeley*(D) and Jack T. Burnett \\ School of Forestry, College of the Environment, Forestry, and Natural Sciences, Northern Arizona University, \\ P.O. Box 15018, Flagstaff, AZ 86011, USA; jtb438@nau.edu \\ * Correspondence: catrin.edgeley@nau.edu
}

Received: 22 July 2020; Accepted: 6 August 2020; Published: 9 August 2020

check for updates

\begin{abstract}
COVID-19 has complicated wildfire management and public safety for the 2020 fire season. It is unclear whether COVID-19 has impacted the ability of residents in the wildland-urban interface to prepare for and evacuate from wildfire, or the extent to which residents feel their household's safety has been affected. Several areas with high wildfire risk are also experiencing record numbers of COVID-19 cases, including the state of Arizona in the southwestern United States. We conducted a mixed-mode survey of households in close proximity to two recent wildfires in rural Arizona to better understand whether residents living in the wildland-urban interface perceive COVID-19 as a factor in wildfire safety. Preliminary data suggest that the current challenges around collective action to address wildfire risk may be further exacerbated due to COVID-19, and that the current pandemic has potentially widened existing disparities in household capacity to conduct wildfire risk mitigation activities in the wildland-urban interface. Proactive planning for wildfire has also increased perceived ability to practice safe distancing from others during evacuation, highlighting the benefits that household planning for wildfire can have on other concurrent hazards. Parallels in both the wildfire and pandemic literature highlight vast opportunities for future research that can expand upon and advance our findings.
\end{abstract}

Keywords: COVID-19; wildfire; evacuation; public safety; public health; pandemic; emergency management; risk mitigation; social distancing; concurrent hazards

\section{Introduction}

Both public and firefighter health have become central to conversations around the 2020 wildfire season due to ongoing risks associated with the global COVID-19 pandemic. COVID-19 is a respiratory disease caused by the virus SARS-CoV-2 that can lead to death in the most severe cases $[1,2]$. Its emergence and continued international spread in late 2019 and early 2020 resulted in widespread restrictions on travel and social activities in an effort to mitigate virus transmission. More recently, concerns about the intersection of wildfire season with pandemic risk (herein referred to as the wildfire-pandemic interface) indicate that there may be opportunities for heightened COVID-19 infection and spread in addition to restricted emergency communication and disaster management capacity, under rapidly evolving conditions [3,4]. Understanding how residents in the wildland-urban interface (WUI) - areas where vegetation meets development-may perceive and adapt to these concurrent risks, and how they might behave if a wildfire threatens their home, is therefore an urgent research need. We explore this knowledge gap through a preliminary analysis of survey data collected ahead of the 2020 fire season in two WUI areas in the U.S. state of Arizona.

COVID-19 has drastically altered U.S. wildfire management and associated organization efforts, predominantly due to concerns about infection rates among firefighting crews and in fire camps 
that might reduce agency capacity to provide rapid suppression response $[5,6]$. This is particularly challenging as some incident response efforts depend on shared resources and personnel, and evolving travel restrictions may restrict opportunities to request aid both nationally and internationally for larger incidents $[7,8]$. The potential for reduced firefighting capacity may increase risk for communities threatened by wildfires this season; however, it is not known whether the public-particularly WUI residents - are aware of the potential limitations of firefighting during COVID-19. Efforts to understand potential public interactions with wildfire and COVID-19 risk simultaneously in this article are focused on household actions and perceived safety associated with suppression response under these emergent WUI conditions

Evolving contexts surrounding how people interact with their homes and property under the "shelter-in-place" or stay at/work from home advisories due to COVID-19 suggest opportunities for a potential departure from previous efforts to mitigate fire risk on private property. On one hand, increased time at home may provide new windows of time for mitigation activities; on the other, there may be additional responsibilities, or protective actions that prioritize health and wellbeing, that could limit such efforts. The postponement of numerous prescribed burns by the U.S. Forest Service and other agencies in the spring of 2020 due to COVID-19 may further extend the risks associated with untreated fuel near WUI communities [9]. Education efforts, such as the National Fire Protection Association's Wildfire Community Preparedness Day (typically held in early May), have also been impacted by the pandemic, which might have affected awareness and risk reduction among some populations. Concerns about rural healthcare capacity amidst a sudden swell in public lands use led to requests for tourists to stay away from rural, recreation-dependent communities like Moab, UT [10-12] — concerns that were echoed in rural WUI communities with high rates of second home ownership, such as recreation cabins [13]. It is unclear whether COVID-19 travel advisories have disproportionally impacted part-time residents' or second homeowners' ability to conduct property-level mitigation at these properties. Encouraging collective action at the community level to reduce wildfire risk is already a challenging endeavor; disruptions caused by COVID-19 this year have the potential to further fragment social adaptation to fire $[14,15]$.

Questions about evacuation safety and possible changes in behavior have also emerged around COVID-19 and wildfire risk [16,17]. It is unknown whether residents in fire-prone areas believe they would be able to practice safe distancing from others during an evacuation, as many evacuees may have to temporarily stay in close proximity with others. Evacuation shelters have already presented complex health management challenges during the 2020 hurricane season [4], and existing studies document how shelters can allow the rapid spread of illness; at least 292 evacuees across nine shelters were diagnosed with norovirus after evacuating from the Camp Fire in 2018 [18]. Other common options such as staying with family or friends or in hotels can further increase opportunities for virus transmission $[3,19,20]$. Emergency management and education programs in the U.S. also advise early evacuation when threatened by wildfire, while messaging about COVID-19 safety advises people to stay at home; it is possible that simultaneous communication of these two messages may cause confusion or uncertainty at the household level [21,22]. Research also indicates that many residents in WUI areas expect to be notified in person about whether to evacuate [21,23]. While this is rarely feasible under normal conditions, face-to-face communication about wildfire risk will likely be further restricted by COVID-19, which may place some WUI residents at greater risk [16].

Risk perceptions play a significant role in public response to both wildfire and COVID-19. Current research indicates that more tangible risks often take higher priority in household- and individual-level adaptation efforts, but the time, effort and expertise required to perform adaptive actions can also influence decisions to act [24,25]. Existing studies of both COVID-19 and wildfire risk perceptions indicate that men perceive lower risk from both hazards in comparison to women [26-28], which may lead to a continued gender divide in risk-taking where these two hazards converge. Furthermore, optimism bias - the belief that others are more likely to experience negative consequences than oneself-has been identified in studies of both COVID-19 risk perceptions and wildfire impacts or 
evacuation $[26,29,30]$. Understanding how emergent research on COVID-19 risk perceptions aligns with wildfire risk research offers a novel opportunity for exploring how WUI residents navigate multi-hazard environments.

The presence of two or more hazards simultaneously is not new; a majority of communities globally face a multitude of risks at any given time, although the probability of those events happening concurrently can be highly variable $[3,31]$. Many existing efforts examine how residents navigate competing risks, with a particular focus on identifying which factor(s) drive how residents prioritize or perceive these hazards. While quantitative studies suggest that basic demographic variables like gender, age and income influence household risk perceptions and responses in multi-hazard environments [32,33], qualitative studies highlight the importance of more nuanced factors, like past experience with hazards, local culture, and trust in organizations and agencies to mitigate and communicate risk [34,35]. Regardless of methodology, existing multi-hazard studies typically investigate how households negotiate different environmental risks (e.g., hurricanes, floods, chemical releases, wildfires), rather than a mix of environmental and health hazards [36]. The melding of wildfire and pandemic risk is of added importance due to reported increases in infection associated with low air quality events like wildfire smoke $[37,38]$; it has direct impacts on hospital capacity and the potential to disproportionately affect those with pre-existing health conditions. Research at the wildfire-pandemic interface is critical as COVID-19 persists, and findings may offer guidance for risk communication, health resource allocation and emergency management as concurrent hazard events become increasingly common.

Arizona's 2020 fire season began with a multitude of wildfires that led to mass evacuations in both rural and urban areas. In June, the Mangum Fire burned the north rim of the Grand Canyon, while the Bighorn Fire approached Tucson and the Sawtooth and Bush Fires pushed smoke across the Southwest [39]. Simultaneously, new COVID-19 cases in Arizona reached record highs as "stay at home" advisories were relaxed [40]. These converging hazards highlight a multi-layered challenge for evacuation and public safety this year, and present an opportunity for time-sensitive data collection that can inform health and emergency management considerations for future risks. Given that no vaccine has been developed for COVID-19 at this time, there is a possibility that communities and fire professionals could see multiple fire seasons where wildfire and COVID-19 risks converge. We explore this intersection of wildfire and pandemic risk in two areas recently affected by wildfire using a mixed-mode survey conducted in late spring of 2020, working to address the following research question: To what extent did COVID-19 influence Arizona residents' anticipated interactions with wildfire risk ahead of the 2020 wildfire season?

\section{Materials and Methods}

\subsection{COVID-19 Context for Study Design and Sample Frame}

This study emerged through an opportunistic modification made to a pre-existing project focused on resident health after recent wildfires in Arizona. The authors designed a survey instrument and finalized the sample frame in mid-March 2020 and were preparing to administer it when Arizona State Governor Doug Ducey announced a public health emergency on 12th March. The authors rapidly developed a short subset of survey questions to insert into the survey booklet before sending the finalized materials to print in late March. Shortly after, Governor Ducey issued a state-wide "stay at home" executive order that lasted from close of business on 31st March until 15th May. All but five U.S. states implemented some form of stay at home order, with a further three states introducing orders only in certain parts [41]. State-level restrictions and stay at home orders began to lift in May, followed by a rapid resurgence and record-breaking numbers of new COVID-19 cases in many areas. A recent survey of registered voters in Arizona indicated that those whose views aligned closest with the Republican party were far less concerned about state-level COVID-19 spread than respondents aligned with other parties, which may add an additional layer to the complexity of this survey data that 
is not captured in our analysis, specifically regarding optimism bias and reduced risk perceptions [42]. We consider our study to be preliminary due to its rapid and opportunistic development as an additional component within an existing study. It is not yet clear how this survey's response rate compares with other similar surveys with a predominantly non-COVID-19 focus administered to rural populations during and after state-wide stay at home orders.

The authors developed a comprehensive list of all wildfires that occurred in Arizona between 2015 and 2019, created by systematically reviewing entries from a range of sources, including government-managed websites like Inciweb, local and national news reports, and the Monitoring Trends in Burn Severity database. The four-year timeframe for the search was determined in order to support respondent recall of recent fire events. This initial database was narrowed down to fires that had resulted in one or more social impacts by identifying the presence of existing indicators reported in the literature (such as structure loss and evacuation) using Paveglio et al.'s [43] summary to structure our search. This process resulted in seven shortlisted wildfires. The authors then collected additional information on those events, including more comprehensive news coverage and GIS data, before conducting field visits and key informant interviews in several locations. Through this process, the Goodwin Fire and the Tinder Fire were identified as suitable study areas for the original purpose of this survey as they resulted in social impacts that exceeded those of all other recent fires.

The Goodwin Fire started 24th June 2017 near the town of Mayer (Figure 1). Between 24th June and 10th July 2017, approximately 28,516 acres burned. The cause of the fire has yet to be reported. The Tinder Fire was ignited by an abandoned campfire in the Blue Ridge area near Happy Jack, growing rapidly to 16,309 acres from 27th April to 24th May 2018. Both fires resulted in county-level state of emergency declarations by the Arizona State Governor, widespread evacuation, and in the case of the Tinder Fire, 33 primary residences and 54 non-residential structures were destroyed [44]. The rural communities surrounding the perimeters of each fire were diverse; populations near the Goodwin Fire generally reported lower household incomes with a mix of trailers, RVs and manufactured homes, while the Tinder Fire area had a greater mix of second homes and vacation cabins clustered within a patchwork of small subdivisions. Both fire areas represent different examples of WUI environments and conditions; the area impacted by the Tinder Fire was largely forested with ponderosa pine, while the Goodwin Fire area was mostly interior chapparal, dominated by shrub oak and grasses.

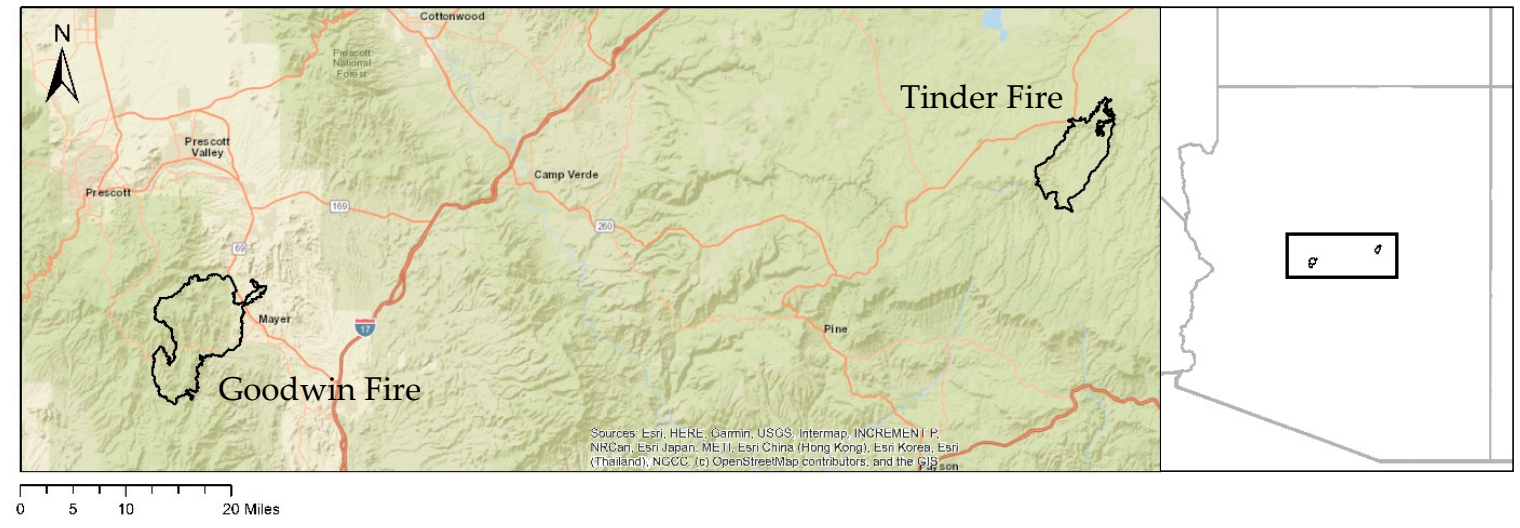

Figure 1. Locations of the Goodwin (left) and Tinder Fires (right) within Arizona.

\subsection{Survey Design and Administration}

The sample frame for this survey was determined based on whether each address met either or both of the following criteria: (1) the property was located within one mile of each fire's burn perimeter; and (2) whether they had been placed under evacuation during the fire event at any level of the "Ready, Set, Go" system. Properties that met these criteria were identified in ArcGIS using parcel data provided by Yavapai and Coconino Counties. Through this process, 655 homes were included in the sample frame for the Goodwin Fire and 781 for the Tinder Fire, for a total of 1436 addresses. Each property 
was assigned its own unique identifying code to organize survey administration, track mail returns, and to allow online survey access [45].

Survey administration was designed in accordance with Dillman et al. [46] following the Tailored Design Method. Survey materials were mailed in three phases beginning in early April: (1) the initial survey packet, containing an introductory letter, the survey booklet and a business reply envelope; (2) a reminder postcard that shared information on participating online; and (3) a final reminder postcard. The online survey was identical to the paper survey questions. Arizona's "stay at home" order was lifted between the second and third mailing in this study. Completed questionnaires were dated as they were received, and comparative statistics indicate no statistically significant differences in survey responses before and after the order was lifted.

Questions spanned several topics, including: (1) COVID-19 and the 2020 fire season; (2) household efforts to prepare for wildfire; (3) experiences with the Goodwin or Tinder Fire, including evacuation, impacts, and broader health and wellbeing questions; and (4) basic socio-demographic information, including age, gender, income, education and ethnicity. COVID-19 questions were developed with consideration of news articles and reports that were emerging in March that raised concerns about the forthcoming fire season in relation to health risk management. We refer to these questions as our "wildfire-pandemic interface" question set. These statements are listed below in Table 1 and were intentionally designed to be broad in order to capture the wide range of potential actions and behaviors respondents might undertake. Questions also asked whether the respondent was observing any "stay at home" orders, and whether anyone in their household had been formally or informally diagnosed with COVID-19. The section regarding efforts to prepare for wildfire asked respondents to report whether they had conducted any or all of the following six actions, replicated from Edgeley and Paveglio [21]: discussed with their neighbor what their household would do during a fire, identified at least one evacuation route, placed important documents and belongings in an easy to access place, identified somewhere to stay during evacuation, had tools or equipment that could be used to fight fire on their property, and had created defensible space around their home.

We received 301 completed surveys for a response rate of $21.0 \%$. Of these responses, 130 were completed by households in the Goodwin Fire area (19.9\% response rate) and 171 by households in the Tinder Fire area (21.9\% response rate). Given that both surveyed areas are rural and COVID-19 restrictions were in place during survey administration, we consider this response rate acceptable and in line with existing research. This response rate provides at least a $95 \%$ confidence interval ( $\pm 5 \%$ sampling error) based on our sample population size [47]. Only eight respondents resided outside the state of Arizona; these respondents' responses were not statistically different from those received from in-state addresses.

Although the Goodwin and Tinder Fires were selected for this survey based on social impacts, it may be helpful to consider the socio-demographic characteristics of survey respondents given their suggested importance in emerging studies on COVID-19. The average survey respondent was approximately 66 years old. Approximately $61.7 \%$ of respondents were male and $37.9 \%$ were female; a further $0.4 \%$ identified as non-binary or other. The majority of respondents $(93.5 \%)$ were white. $44.5 \%$ of respondents had completed education to at least a Bachelors or other four-year degree level. More than half (52.1\%) of the respondents were full time residents in one of our two study areas. The other survey respondents either spent less six months or less at their property (12.3\%) or visited regularly for short periods of time $(36.4 \%)$, while $1.4 \%$ rented their property to others. The median annual household income (before taxes) between 2014 and 2018 for the state of Arizona was $\$ 56,213$ USD [48]; $60.4 \%$ of our respondents reported annual household income totaling $\$ 60,000$ USD or more. We suggest this higher income may be driven by participants who own second homes in the study areas. 


\subsection{Analysis}

Completed survey responses were entered, cleaned and analyzed using SPSS 26 [49]. Given that almost half of the respondents are second homeowners who live outside the study areas, we decided not to separate this data by fire for the analysis. First, descriptive statistics and exploratory analysis of data distribution were conducted for the dataset. We sought to identify significance across our five wildfire-pandemic statements using a combination of one-way ANOVA tests for Likert-scale questions, and Pearson's Chi-Square and one-sided Fisher's Exact Tests for binary questions. Post-hoc z-tests with a Bonferroni correction provided comparative analysis across responses. Given the evolving nature of the situation surrounding COVID-19 and the 2020 wildfire season and the modest size of our dataset, we opted to keep our analysis relatively simple. Our goal here is to provide rapid analysis of time-sensitive data for immediate use.

\section{Results}

Only two respondents $(0.7 \%)$ reported that someone in their household had a confirmed or suspected case of COVID-19. Approximately $76.1 \%$ of respondents were following state- or local-level stay at home orders; $17.8 \%$ were not because they were considered "essential" employees, and $4.7 \%$ reported that they were not following state-level stay at home recommendations ("business as usual"). A further 1.4\% lived in states without any COVID-19 restrictions at the time they completed the survey. A comparison of surveys received before $(n=253)$ and after Arizona's state-wide "stay at home" order was lifted $(\mathrm{n}=48)$ presented no statistically significant differences in response. Question responses related to COVID-19 did not vary significantly between the Tinder and Goodwin Fire sample frames. Nearly half $(49.8 \%)$ of respondents indicated that they or someone in their household has a pre-existing health condition, and $22.0 \%$ indicated that someone in their household had a disability. Most respondents' $(84.2 \%)$ properties had been placed under some level of evacuation notice during the Goodwin or Tinder Fire, while $7.9 \%$ of respondents had lived at a property placed under evacuation prior to those fire events.

Table 1 presents the response distribution for our five wildfire-pandemic interface statements focused explicitly on COVID-19 and the 2020 wildfire season. Overall, few respondents reported that COVID-19 would affect household preparation, evacuation plans and safety during the 2020 fire season. Across these statements, the majority of respondents tended to lean towards one extreme or the other. Almost half of the respondents (48.8\%) strongly disagreed that COVID-19 would change their evacuation plans; for context, $54.1 \%$ of respondents had planned at least one evacuation route for their household, and $67.3 \%$ had somewhere to stay during an evacuation. The majority of respondents did not anticipate any issues with maintaining a safe distance from others when evacuating, and also disagreed that COVID-19 had reduced household safety during a wildfire. Additionally, few respondents agreed that COVID-19 had prevented them from preparing their Goodwin or Tinder Fire area property this year. There was greater uncertainty among respondents about whether firefighting response would be impacted by COVID-19, with the highest number of respondents remaining neutral.

Chi-square tests indicated that some individual variables had relationships that were significant for better understanding how survey participants responded to wildfire-pandemic questions. Two groups of respondents were less likely to have prepared their property for wildfire this year due to COVID-19: households where someone with a disability lived $(p=0.024 * ; 14.5 \%$ agreed or strongly agreed, compared with $12.1 \%$ of non-disability reporting homes) and part-time residents ( $p=0.001 * *$; $20 \%$ strongly or moderately agreed, compared to $6.1 \%$ of full-time respondents). The latter could possibly be due to restricted travel to second homes under government-implemented COVID-19 management efforts, such as stay at home orders. Respondents who had observed the state stay at home order were also significantly more likely to agree that firefighting response in their area would be impacted by COVID-19 this year $\left(p=0.023^{*}\right)$. Notably, there was no statistically significant difference in responses to wildfire-pandemic interface measures between households where residents with pre-existing health conditions lived and households without such residents. 
Differences in actions regarding the stay at home order appeared to have a significant influence on answers to wildfire-pandemic questions. Those who chose to observe the stay at home order were more likely to agree that COVID-19 would change their evacuation plans when compared with those who chose not to $\left(p=0.045^{*}\right)$. Respondents who reported that they were considered "essential workers" and therefore could not work from home were more likely to agree that COVID-19 had prevented them from conducting mitigation work on their property $\left(p=0.007^{* *}\right)$. Those who observed the stay at home order were also more likely to agree that firefighting response would be impacted when compared with those who chose not to stay at home $\left(p=0.002^{* *}\right)$. Comparative responses across different actions are shown in Table 2, highlighting the fact that there are significant differences across groups regarding wildfire-pandemic statements. Despite differences between groups, average responses to each statement demonstrate that respondents still collectively leant consistently towards disagreement or agreement.

Table 1. Distribution of survey wildfire-pandemic interface measures $(\alpha=0.637)$ in response to the prompt "Please indicate the extent to which you agree or disagree with the following statements about COVID-19 during this coming fire season." Most frequent responses are presented in bold.

\begin{tabular}{ccccccc}
\hline & $\begin{array}{c}\text { Strongly } \\
\text { Disagree }\end{array}$ & $\begin{array}{c}\text { Moderately } \\
\text { Disagree }\end{array}$ & $\begin{array}{c}\text { Neither } \\
\text { Agree nor } \\
\text { Disagree }\end{array}$ & $\begin{array}{c}\text { Moderately } \\
\text { Agree }\end{array}$ & $\begin{array}{c}\text { Strongly } \\
\text { Agree }\end{array}$ & $N$ \\
\hline $\begin{array}{c}\text { COVID-19 would change my } \\
\text { wildfire evacuation plans } \\
\text { I could evacuate from a }\end{array}$ & $\mathbf{4 8 . 1 \%}$ & $13.4 \%$ & $21.2 \%$ & $13.4 \%$ & $3.9 \%$ & 283 \\
$\begin{array}{c}\text { wildfire and still practice safe } \\
\text { distancing from others }\end{array}$ & $9.1 \%$ & $7.0 \%$ & $10.1 \%$ & $25.2 \%$ & $48.6 \%$ & 286 \\
$\begin{array}{c}\text { COVID-19 has reduced my } \\
\text { household's safety during a } \\
\text { wildfire }\end{array}$ & $\mathbf{4 5 . 6 \%}$ & $17.3 \%$ & $20.8 \%$ & $13.4 \%$ & $2.8 \%$ & 283 \\
$\begin{array}{c}\text { COVID-19 has prevented me } \\
\text { from preparing my property } \\
\text { for wildfire this year }\end{array}$ & $\mathbf{6 5 . 6 \%}$ & $13.3 \%$ & $8.4 \%$ & $8.4 \%$ & $4.2 \%$ & 285 \\
$\begin{array}{c}\text { Firefighting response during } \\
\text { a wildfire in my area will be } \\
\text { impacted by COVID-19 }\end{array}$ & $26.8 \%$ & $10.9 \%$ & $33.8 \%$ & $21.5 \%$ & $7.0 \%$ & 284 \\
\hline
\end{tabular}

Table 2. Average wildfire-pandemic interface measures categorized by response to stay at home order. Subscripts indicate which stay at home order response categories differ at the 0.05 error level. Probabilities are significant at: $p \leq 0.050^{*}, p \leq 0.010^{* *}$ and $p \leq 0.001^{* * *}$. Respondents whose states did not have any COVID-19 restrictions were removed from this analysis due to its small $N$.

\begin{tabular}{|c|c|c|c|c|c|}
\hline & $\begin{array}{l}\text { Stay at } \\
\text { Home }\end{array}$ & $\begin{array}{l}\text { Business as } \\
\text { Usual }\end{array}$ & $\begin{array}{l}\text { Essential } \\
\text { Worker }\end{array}$ & $\mathbf{F}$ & Sig. \\
\hline $\begin{array}{l}\text { COVID-19 would change my wildfire } \\
\text { evacuation plans }\end{array}$ & $-0.79 \mathrm{a}$ & $-1.60_{b}$ & -1.04 & 3.510 & 0.031 * \\
\hline $\begin{array}{l}\text { I could evacuate from a wildfire and still } \\
\text { practice safe distancing from others }\end{array}$ & 0.98 & 0.69 & 1.00 & 0.389 & 0.068 \\
\hline $\begin{array}{l}\text { COVID-19 has reduced my household's } \\
\text { safety during a wildfire }\end{array}$ & -0.81 & -1.50 & -1.75 & 2.819 & 0.061 \\
\hline $\begin{array}{l}\text { COVID-19 has prevented me from } \\
\text { preparing my property for wildfire this } \\
\text { year }\end{array}$ & $-1.14_{a}$ & -1.75 & $-1.70_{b}$ & 6.719 & $0.001^{* *}$ \\
\hline $\begin{array}{l}\text { Firefighting response during a wildfire in } \\
\text { my area will be impacted by COVID-19 }\end{array}$ & $-0.16 a$ & $-1.25_{b}$ & -0.47 & 6.513 & $0.002 * *$ \\
\hline
\end{tabular}

Household planning for wildfire was also a driver of responses to wildfire-pandemic interface questions. Households that reported a higher number of wildfire planning actions were more confident that they could safely distance from others during evacuation $\left(p=0.035^{*}\right)$. When examining specific actions, this was reinforced further. Respondents who had placed important documents in a safe place 
felt more confident about safe distancing during evacuation $(p=0.021 *)$. Those who had taken steps to prepare for wildfire tended to be less optimistic about household safety at the wildfire-pandemic interface; for example, respondents who had talked with their neighbors about their plans were more likely to agree household safety had decreased $\left(p=0.034^{*}\right)$. Respondents from a household where someone with a pre-existing health condition lived were more likely to have somewhere to stay during an evacuation $(p=0.042 *)$. Respondents who reported that they had firefighting equipment on their property were distinctly different from other respondents, and were less likely to agree that COVID-19 had reduced firefighting capacity in their area $\left(p=0.027^{*}\right)$. It is possible that these respondents planned to stay and defend their property regardless of the context surrounding a wildfire event. Those who had not taken proactive efforts to prepare for evacuation were also less likely to agree that COVID-19 would change their evacuation plans-despite the fact that these households indicated that they did not have a plan to begin with $\left(p=0.016^{*}\right)$.

\section{Discussion}

This study sought to establish a preliminary baseline for WUI resident expectations of how COVID-19 might influence their experiences with the 2020 fire season. Although our analysis was relatively simple, we identified several important outcomes that can influence wildfire-pandemic management and communication. Overall, respondents were optimistic that COVID-19 would not affect how their household intended to respond to wildfire risk, including ability to maintain a safe distance from others, although there was greater uncertainty about what COVID-19 might mean for firefighting response in their area. Those who were able to follow the stay at home order in Arizona tended to report slightly greater concern about their ability to maintain household safety at the wildfire-pandemic interface. Our data suggest that some existing inequities in ability to prepare for wildfire are further exacerbated at the wildfire-pandemic interface; essential workers and households with residents that had disabilities were less likely to have prepared their property for wildfire due to COVID-19, alongside second homeowners. Finally, those who had made proactive efforts to prepare for wildfire were most confident that they could evacuate while distancing from others, and were less likely to report that COVID-19 had changed their evacuation plans. These findings can help professionals working at the wildfire-pandemic interface better anticipate WUI resident needs and concerns, and may be of value to fire professionals in the southern hemisphere as their 2020-2021 fire season begins.

A vast body of wildfire social science literature documents divergent perceived and actual mitigation efforts between full-time and part-time residents [14,50-52]. Our data suggest that opportunities for social conflict associated with this divergence may be further exacerbated by COVID-19, given that part-time residents were more likely to report that COVID-19 had prevented them from conducting mitigation on their properties. This creates a catch-22 for second homeowners; if they do not visit their property to minimize virus spread, they are unable to support collective action within their community-however, if they do visit their property, they risk creating an undue burden on rural communities and health-care services. Looking forward, professionals who interact with WUI communities should be aware that there may be social repercussions for second homeowners, caused in part by COVID-19 restrictions. This pandemic has potentially long-lasting implications for community cohesion around wildfire risk, particularly if the risks associated with COVID-19 span multiple fire seasons.

Respondents tended to indicate low risk perceptions when asked how the 2020 wildfire-pandemic interface might affect them, which indicates a need for continued education and outreach at the intersection of these concurrent hazards. We suggest that this may indicate potential optimism bias, as reported in other wildfire- and COVID-19-focused research $[26,29,30]$. While U.S. governments and agencies are rapidly gaining experience communicating at the wildfire-pandemic interface, discussions around how these two risks intersect have remained largely within healthcare and emergency management forums (e.g., [4,53]). Opening these multi-hazard discussions to the public-particularly 
WUI residents-offers an opportunity to communicate about two risks simultaneously. Greater uncertainty in responses regarding how firefighting capacity might be affected by COVID-19 suggests that respondents are not sure how wildfire response and virus risk might intersect; this may be a chance for discussion that can promote greater implementation of wildfire mitigation actions on private property.

Our data suggest that those who have already taken proactive measures to prepare for wildfire are far more confident protecting the safety of household members during an evacuation by practicing safe "social distancing." This reinforces and expands upon decades of research highlighting the importance of household-level risk mitigation and planning in advance of a hazard event [50-52]. Encouraging households to plan for wildfire before and during health epidemics and pandemics may provide improved human safety during wildfire and other hazard evacuations; particularly as it appears that evacuation may be one instance where these two hazards are highly likely to directly overlap. This may also be an opportunity to better incorporate health risk reduction into wildfire (and other hazard) education and outreach-for example, health hazards like smoke and heat stroke, in addition to viruses. Incorporating actions and education strategies that can help households think about and plan for concurrent risks more holistically may offer new paths to increased fire adaptation, and improve community resilience.

There are several key limitations to our study. Our study sample frame focused on two populations that have recently experienced fire; therefore, their responses may be different from those of other WUI communities where fire has not occurred, or occurred more than two or three years ago. Numerous researchers highlight that WUI communities are socially diverse (e.g., [54,55]), and we hope that future research can advance understandings of how different WUI populations may respond and recover at the wildfire-pandemic interface. Additionally, both study areas are rural, and may not necessarily reflect how urban populations, or the population of Arizona more broadly, might respond to concurrent hazards. However, this may be mitigated to some degree by the fact that almost half our respondents were second homeowners, many of whom live in urban centers like Phoenix. Socio-demographic data indicate that our survey overrepresents men, older residents, and households that have residents with disabilities when compared to Arizona's most recent census data [48]. A vast body of literature in wildfire, general hazard and health fields consistently demonstrates that men perceive lower levels of risk when compared with women (e.g. $[26,27,56])$. We propose that this gender overrepresentation may be due to the broader focus of the survey on wildfire, which may appeal more to this population than others.

Opportunities for future research to understand resident experiences at the wildfire-pandemic interface are vast, particularly as seasonal fire conditions shift from the northern to southern hemisphere. Numerous large WUI fires in Arizona and beyond during the 2020 season to date present openings to study whether evacuation during wildfire really did create challenges for safe distancing, and whether it may have caused changes in infection rates or community spread. Specifically, studies of how COVID-19 impacts different components of household evacuation experiences during fire (e.g., evacuation or its alternatives, versus evacuation destinations and experiences sheltering in those locations) are needed to understand which components of evacuation experiences present the highest risk of transmission. This also can help identify where households are most likely to diverge from intended behaviors or planned actions due to COVID-19, helping to pinpoint where emergency management efforts should focus. Additionally, data exploring why evacuees do or do not use shelters can inform shelter planning in order to emphasize safety and the needs or expectations of users during pandemics or other health risks. "Ground-truthing" perceived risks and impacts reported ahead of this fire season after wildfire events can provide insights into more effective communication and strategic emergency management planning to better anticipate associated behaviors in subsequent years.

Understanding the impact of this year's wildfires and related evacuation behaviors on health inequities offers yet another avenue for examining whether COVID-19 has exacerbated pre-existing variations in vulnerability. We did not find many significant differences in wildfire-pandemic 
perceptions for households with pre-existing health conditions or disabilities, aside from evacuation planning and the ability to conduct mitigation on private property, which is surprising given that existing studies demonstrate that these populations are among the most vulnerable to COVID-19 [57-59]. We suggest that further research is needed in order to understand whether or not this is unique to our study population. Furthermore, our survey questions were developed and administered prior to much of the emergent research concerning how reduced air quality might heighten risk of COVID-19 infection; there are numerous avenues for research to understand this variation in concurrent hazards and the risk it might pose to household health and safety. There are abundant opportunities to expand our knowledge of concurrent risks for WUI residents in the U.S. and elsewhere over the coming months that can lead to improved public safety and wildfire management as we face an uncertain future.

\section{Conclusions}

The COVID-19 pandemic has created a vast number of new uncertainties for the 2020 fire season. WUI residents must now navigate life at the wildfire-pandemic interface, resulting in seemingly diverse household responses in Arizona. These diverse responses to concurrent risks may have cascading social consequences in future years, particularly around issues like mitigation on private property that already create challenges in some WUI communities. Fire professionals and local governments should anticipate potential conflicts and inequalities in WUI communities stemming from this year's wildfire-pandemic interactions as they plan for the forthcoming months and years. Pre-COVID-19 actions reported by respondents in this study highlight the importance of looking at existing social contexts to investigate the capacity of WUI residents to protect themselves when hazards occur concurrently. There is a clear and urgent need for more research to understand perceived and actual risk before, during and after wildfire events during this pandemic, in order to limit virus spread while maximizing household and community safety. Given our rapidly changing climate and population combined with consistently complex and challenging wildfire seasons internationally, data collected at this nexus may hold value not only for COVID-19 but also for other concurrent hazards that the future will bring.

Author Contributions: Conceptualization, C.M.E. and J.T.B.; methodology, C.M.E. and J.T.B; investigation, C.M.E. and J.T.B; data curation, C.M.E.; formal analysis, C.M.E.; writing-original draft preparation, C.M.E.; writing - review and editing, C.M.E. and J.T.B; supervision, C.M.E.; project administration, C.M.E.; funding acquisition, C.M.E. All authors have read and agreed to the published version of the manuscript.

Funding: This research was supported by a National Institute on Minority Health and Health Disparities (NIMHD) Center grant to the Southwest Health Equity Research Collaborative at Northern Arizona University (U54MD012388) and McIntire-Stennis appropriations to Northern Arizona University and the State of Arizona.

Acknowledgments: The authors would like to express their gratitude to undergraduate research assistants Margaret Sichrovsky and Solena Daniels for their assistance with survey preparation and data entry, and to residents in the vicinity of the Goodwin and Tinder Fires who gave their time to complete this survey.

Conflicts of Interest: The authors declare no conflict of interest. The funders had no role in the design of the study; in the collection, analyses, or interpretation of data; in the writing of the manuscript, or in the decision to publish the results.

\section{References}

1. CDC. Symptoms of Coronavirus. Available online: https://www.cdc.gov/coronavirus/2019-ncov/symptomstesting/symptoms.html (accessed on 6 June 2020).

2. Sohrabi, C.; Alsafi, Z.; O’Neill, N.; Khan, M.; Kerwan, A.; Al-Jabir, A.; Losifidis, C.; Agha, R. World Health Organization declares global emergency: A review of the 2019 novel coronavirus (COVID-19). Int. J. Surg. 2020, 76, 71-76. [CrossRef] [PubMed]

3. Quigley, M.C.; Attanayake, J.; King, A.; Prideaux, F. A multi-hazards earth science perspective on the COVID-19 pandemic: The potential for concurrent and cascading crises. Environ. Syst. Decis. 2019, 40, 199-215. [CrossRef] [PubMed] 
4. FEMA. COVID-19 Pandemic Operational Guidance for the 2020 Hurricane Season. Available online: https://www.fema.gov/media-library-data/1589997234798-adb5ce5cb98a7a89e3e1800becf0eb65/2020_ Hurricane_Pandemic_Plan.pdf (accessed on 7 July 2020).

5. Thompson, M.P.; Bayham, J.; Belval, E. Potential COVID-19 Outbreak in Fire Camp: Modeling Scenarios and Interventions. Fire 2020, 3, 28. [CrossRef]

6. Riley, K. On COVID-19 Epidemiology, with Application to Wildland Fire Management Practices. USDA For. Serv. 2020. Available online: https://static1.squarespace.com/static/5ea4a2778a22135afc733499/t/ 5ec2ce99362e25141c647298/1589825177861/Riley_On_+COVID19.pdf (accessed on 21 July 2020).

7. Moore, P.; Hannah, B.; de Vries, J.; Poortvliet, M.; Steffens, R.; Stoof, C.R. Wildland Fire Management under COVID-19. Brief 1, Review of Materials; Wageningen University: Wageningen, The Netherlands, 2020. [CrossRef]

8. Stoof, C.R.; de Vries, J.R.; Poortvliet, M.; Hannah, B.; Steffens, R.; Moore, P. Preview Brief 2: Wildland Fire Management under COVID-19, Survey Results; Wageningen University: Wageningen, The Netherlands, 2020. [CrossRef]

9. Carlisle, N. Prescribed Burns Are Canceled in Utah and across the West as Coronavirus Meets Wildfire Season. The Salt Lake Tribune, 3 April 2020. Available online: https://www.sltrib.com/news/politics/2020/04/ 03/prescribed-burns-are/ (accessed on 9 July 2020).

10. Carson, J.A. Rural Areas with Seasonal Homes Hit Hard by COVID-19. Data Snapshot, University of New Hampshire Carsey School of Public Policy, 8 April 2020. Available online: https://pdfs.semanticscholar.org/6acc/6f0046590480a66cb64ea82728f06eadc5d7.pdf?_ga=2.109396997. 1688375849.1594005450-1848577010.1593038085 (accessed on 21 July 2020).

11. Groetzinger, K. Moab Hospital Medical Director Asks Tourists to Stay away from National Parks. National Public Radio Utah, 17 March 2020. Available online: https://www.kuer.org/post/moab-hospital-medicaldirector-asks-tourists-stay-away-national-parks\#stream/0 (accessed on 9 July 2020).

12. Rice, W.L.; Mateer, T.; Taff, B.D.; Lawhon, B.; Reigner, N.; Newman, P. The COVID-19 Pandemic Continues to Change the Way People Recreate Outdoors: A Second Preliminary Report on a National Survey of Outdoor Enthusiasts amid the COVID-19 Pandemic. Leave No Trace. 2020. Available online: https: //lnt.org/wp-content/uploads/2020/04/COVID_OR_phase-II_final.pdf (accessed on 6 May 2020).

13. Marohn, K. Thinking of Heading to a Cabin to Wait out the Coronavirus? Here Are a Few Things to Consider. Michigan Public Radio, 27 March 2020. Available online: https://www.mprnews.org/story/2020/03/27/ thinking-of-heading-to-a-cabin-to-wait-out-the-coronavirus-here-are-a-few-things-to-consider (accessed on 7 July 2020).

14. Paveglio, T.B.; Carroll, M.S.; Stasiewicz, A.M.; Edgeley, C.M. Social fragmentation and wildfire management: Exploring the scale of adaptive action. Int. J. Disaster Risk Reduct. 2019, 71, 12-23. [CrossRef]

15. Prior, T.; Eriksen, C. Wildfire preparedness, community cohesion and social-ecological systems. Glob. Environ. Chang. 2013, 23, 1575-1586. [CrossRef]

16. Kuligowski, E.D.; Gwynne, S.M.N. Considerations for Planning Community Evacuation during a Pandemic: A Focus on Human Behavior during Wildfire Emergencies. Fire Protection Engineering Magazine, 53 May 2020. Available online: https://www.sfpe.org/page/FPEeXTRAIssue53 (accessed on 21 July 2020).

17. Jowell, A.; Barry, M. COVID-19: A Matter of Planetary, not Only National Health. Am. J. Trop. Med. Hyg. 2020, tpmd200419. [CrossRef]

18. Karmarkar, E.; Jain, S.; Higa, J.; Fontenot, J.; Bertolucci, R.; Huynh, T.; Hammer, G.; Brodkin, A.; Thao, M.; Brousseau, B.; et al. Outbreak of Norovirus Illness Among Wildfire Evacuation Shelter Populations-Butte and Glenn Counties, California, November 2018. Morb. Mortal. Wkly. Rep. 2020, 20, 613-617. [CrossRef]

19. Sorensen, J.H.; Mileti, D.S. Warning and evacuation: Answering some basic questions. Ind. Crisis Q. 1988, 2, 195-209. [CrossRef]

20. Cohn, P.J.; Carroll, M.S.; Kumagai, Y. Evacuation behavior during wildfires: Results of three case studies. West. J. Appl. For. 2006, 1, 39-48. [CrossRef]

21. Edgeley, C.M.; Paveglio, T.B. Exploring influences on intended evacuation behaviors during wildfire: What roles for pre-fire actions and event-based cues? Int. J. Disaster Risk Reduct. 2019, 37, e101182. [CrossRef]

22. Engle, S.; Stromme, J.; Zhou, A. Staying at Home: Mobility Effects of COVID-19. SSRN 2020. [CrossRef] 
23. Howard, A.; Agllias, K.; Bevis, M.; Blakemore, T. "They'll tell us when to evacuate": The experiences and expectations of disaster-related communication in vulnerable groups. Int. J. Disaster Risk Reduct. 2017, 22, 139-146. [CrossRef]

24. McCaffrey, S.; Wilson, R.; Konar, A. Should I stay or should I go now? Or should I wait and see? Influences on wildfire evacuation decisions. Risk Anal. 2018, 7, 1390-1404. [CrossRef] [PubMed]

25. McLennan, J.; Elliott, G.; Omodei, M.; Whittaker, J. Householders' safety-related decisions, plans, actions and outcomes during the 7 February 2009 Victorian (Australia) wildfires. Fire Saf. J. 2013, 61, 175-184. [CrossRef]

26. Eriksen, C.; Gill, N.; Head, L. The gendered dimensions of bushfire in changing rural landscapes in Australia. J. Rural. Stud. 2010, 26, 332-342. [CrossRef]

27. Champ, P.A.; Brenkert-Smith, H. Is seeing believing? Perceptions of wildfire risk over time. Risk Anal. 2016, 36, 816-830. [CrossRef]

28. Dryhurst, S.; Schneider, C.R.; Kerr, J.; Freeman, A.L.; Recchia, G.; van der Bles, A.M.; Spiegelhalter, D.; van der Linden, S. Risk perceptions of COVID-19 around the world. J. Risk Res. 2020, 1-13. [CrossRef]

29. McLennan, J.; Every, D.; Bearman, C.; Wright, L. On the concept of denial of natural hazard risk and its use in relation to householder wildfire safety in Australia. Int. J. Disaster Risk Reduct. 2017, 21, 176-186. [CrossRef]

30. Van Bavel, J.J.; Baicker, K.; Boggio, P.S.; Capraro, V.; Cichocka, A.; Cikara, M.; Crockett, M.J.; Crum, A.J.; Douglas, K.M.; Druckman, J.N.; et al. Using social and behavioural science to support COVID-19 pandemic response. Nat. Hum. Behav. 2020, 4, 460-471. [CrossRef]

31. Slovic, P. The Feeling of Risk: New Perspectives on Risk Perception; Routledge: New York, NY, USA, 2010.

32. Lindell, M.K.; Hwang, S.N. Households' perceived personal risk and responses in a multihazard environment. Risk Anal. 2008, 28, 539-556. [CrossRef]

33. Bronfman, N.C.; Cisternas, P.C.; Repetto, P.B.; Castañeda, J.V. Natural disaster preparedness in a multi-hazard environment: Characterizing the sociodemographic profile of those better (worse) prepared. PLoS ONE 2019, 14, e0214249. [CrossRef] [PubMed]

34. Newman, S.M.; Carroll, M.S.; Jakes, P.J.; Williams, D.R.; Higgins, L.L. Earth, wind, and fire: Wildfire risk perceptions in a hurricane-prone environment. Soc. Nat. Resour. 2014, 27, 1161-1176. [CrossRef]

35. Sullivan-Wiley, K.A.; Gianotti, A.G.S. Risk perception in a multi-hazard environment. World Dev. 2017, 97, 138-152. [CrossRef]

36. Shreve, C.; Begg, C.; Fordham, M.; Müller, A. Operationalizing risk perception and preparedness behavior research for a multi-hazard context. Environ. Hazards 2016, 15, 227-245. [CrossRef]

37. Henderson, S.B. The COVID-19 Pandemic and Wildfire Smoke: Potentially Concomitant Disasters. Am. J. Public Health 2020, e1-e3. [CrossRef]

38. Wu, X.; Nethery, R.C.; Sabath, B.M.; Braun, D.; Dominici, F. Exposure to Air Pollution and COVID-19 Mortality in the United States. 2020. Available online: https://www.medrxiv.org/content/medrxiv/early/2020/ 04/27/2020.04.05.20054502.full.pdf (accessed on 8 August 2020).

39. Inciweb. Inciweb. 2020. Available online: https://inciweb.nwcg.gov/ (accessed on 16 June 2020).

40. AZDHS. Coronavirus Disease 2019 (COVID-19) Data Dashboard. 2020. Available online: https://www.azdhs.gov/preparedness/epidemiology-disease-control/infectious-disease-epidemiology/ covid-19/dashboards/index.php (accessed on 19 July 2020).

41. Mervosh, S.; Lu, D.; Swales, S. See which States and Cities Have Told Residents to Stay at Home. New York Times, 20 April 2020. Available online: https://www.nytimes.com/interactive/2020/us/coronavirus-stay-athome-order.html (accessed on 21 July 2020).

42. Noble, M. Arizonans' Concern Over COVID Lessens Even as Cases Rise. OH Predictive Insights. 2020. Available online: https://ohpredictive.com/category/press-releases/ (accessed on 9 July 2020).

43. Paveglio, T.B.; Brenkert-Smith, H.; Hall, T.; Smith, A.M. Understanding social impact from wildfires: Advancing means for assessment. Int. J. Wildland Fire 2015, 24, 212-224. [CrossRef]

44. Four Forest Restoration Initiative. CFLRP Annual Report: 2018. 2018. Available online: https://www.fs.usda. gov/Internet/FSE_DOCUMENTS/fseprd645995.pdf (accessed on 8 August 2020).

45. Edgeley, C.M. Using Survey IDs to Enhance Survey Research and Administration. J. Ext. 2017, 55, 6TOT3.

46. Dillman, D.A.; Smyth, J.D.; Christian, L.M. Internet, Phone, Mail, and Mixed-mode Surveys: The Tailored Design Method; John Wiley \& Sons: Hoboken, NJ, USA, 2014.

47. Dillman, D.A. Mail and Internet Surveys: The Tailored Design Method; John Wiley \& Sons: Hoboken, NJ, USA, 2000. 
48. US Census Bureau. Quick Facts: Arizona. 2020. Available online: https://www.census.gov/quickfacts/AZ (accessed on 12 July 2020).

49. IBM Corp. IBM SPSS Statistics for Windows; Version 26.0; IBM Corp: Armonk, NY, USA, 2018.

50. Paveglio, T.B.; Kelly, E. Influences on the adoption and implementation of a wildfire mitigation program in an Idaho City. J. For. 2018, 116, 47-54. [CrossRef]

51. Collins, T.W. What influences hazard mitigation? Household decision making about wildfire risks in Arizona's White Mountains. Prof. Geogr. 2008, 60, 508-526. [CrossRef]

52. Champ, J.G.; Brooks, J.J.; Williams, D.R. Stakeholder understandings of wildfire mitigation: A case of shared and contested meanings. Environ. Manag. 2012, 50, 581-597. [CrossRef]

53. Cardil, A.; de-Miguel, S. COVID-19 jeopardizes the response to coming natural disasters. Saf. Sci. 2020. [CrossRef]

54. Paveglio, T.B.; Moseley, C.; Carroll, M.S.; Williams, D.R.; Davis, E.J.; Fischer, A.P. Categorizing the social context of the wildland urban interface: Adaptive capacity for wildfire and community "archetypes". For. Sci. 2015, 61, 298-310. [CrossRef]

55. Paveglio, T.B.; Edgeley, C.M.; Carroll, M.S.; Billings, M.; Stasiewicz, A.M. Exploring the influence of local social context on strategies for achieving fire adapted communities. Fire 2019, 2, 26. [CrossRef]

56. Whittaker, J.; Eriksen, C.; Haynes, K. Gendered responses to the 2009 Black Saturday bushfires in Victoria, Australia. Geogr. Res. 2016, 54, 203-215. [CrossRef]

57. Boccardi, V.; Ruggiero, C.; Mecocci, P. COVID-19: A geriatric emergency. Geriatrics 2020, 5, 24. [CrossRef]

58. CDC. People with Certain Medical Conditions. 2020. Available online: https://www.cdc.gov/coronavirus/ 2019-ncov/need-extra-precautions/people-with-medical-conditions.html?CDC_AA_refVal=https $\% 3 A \%$ 2F\%2Fwww.cdc.gov\%2Fcoronavirus\%2F2019-ncov\%2Fneed-extra-precautions\%2Fgroups-at-higher-risk. html (accessed on 20 July 2020).

59. Guo, W.; Li, M.; Dong, Y.; Zhou, H.; Zhang, Z.; Tian, C.; Qin, R.; Wang, H.; Shen, Y.; Du, K.; et al. Diabetes is a risk factor for the progression and prognosis of COVID-19. Diabetes/Metab. Res. Rev. 2020, e3319. [CrossRef]

(C) 2020 by the authors. Licensee MDPI, Basel, Switzerland. This article is an open access article distributed under the terms and conditions of the Creative Commons Attribution (CC BY) license (http://creativecommons.org/licenses/by/4.0/). 